\title{
Severe Inflammatory Response in Myelodysplastic Syndrome and Trisomy 8 Following 23-Valent Polysaccharide Pneumococcal Vaccine Administration
}

\author{
Trizomi 8 pozitif Myelodisplastik Sendromda 23-Valan Polisakkarit Pnömokok Aşısını \\ Takiben Şiddetli Enflamatuvar Yanıt
}

\author{
(D) Hirohisa Fujikawa1,2, (D) Yusuke Miyazato³, (D) Kenichiro Ebisuda2, (D) Minoru Saito2 \\ ${ }^{1}$ The University of Tokyo, International Research Center for Medical Education, Graduate School of Medicine, Department of Medical Education \\ Studies, Tokyo, Japan \\ 2Suwa Central Hospital, Department of Internal Medicine, Tamagawa, Japan \\ ${ }^{3}$ National Center for Global Health and Medicine, Disease Control and Prevention Center, Tokyo, Japan
}

\section{To the Editor,}

Streptococcus pneumoniae can cause serious diseases such as pneumonia, sepsis, and meningitis. Invasive pneumococcal disease (IPD) is an infection that is confirmed by the isolation of Streptococcus pneumoniae from a normally sterile site (e.g., blood or cerebrospinal fluid). IPD causes significant morbidity and mortality, especially in the elderly and immunocompromised patients. As a widely used vaccine worldwide, the 23-valent polysaccharide pneumococcal vaccine (PPSV23) is safe and effective for vaccination against IPD [1]. Here we report an uncommon case of severe inflammatory response in a patient with myelodysplastic syndrome (MDS) and trisomy 8 following PPSV23 vaccination.

A 65-year-old woman with MDS and trisomy 8 was admitted to the hospital because of a 2-day history of fever $\left(39^{\circ} \mathrm{C}\right)$ and chills. She was given her first injection of PPSV23 (Pneumovax $N{ }^{\circledR}$ ) about $10 \mathrm{~h}$ prior to the onset of symptoms. She had never received a Streptococcus pneumoniae polysaccharide vaccine before. On examination, she was febrile and had pain, redness, and swelling at the injection site on the left upper arm (Figure 1). Laboratory tests showed a white cell count of $14.5 \times 10^{9} / \mathrm{L}$ and C-reactive protein level of $165.4 \mathrm{mg} / \mathrm{L}$. We made the diagnosis of severe inflammatory response following PPSV23 vaccination. She was treated by cooling the affected area and administrating antibiotics, and she recovered within a few days of admission. This adverse event was reported to the Pharmaceuticals and Medical Devices Agency.

MDS is a clonal disorder of myeloid stem cells and is characterized by ineffective and dysplastic hematopoiesis that causes blood cytopenias. Although MDS is a hematological disease, it is frequently associated with various autoimmune disorders, including polymyalgia rheumatica, rheumatoid arthritis, systemic lupus erythematosus, and systemic vasculitis $[2,3]$.
Some case studies indicate a relationship between MDS and Behçet's disease (BD). Trisomy 8 plays a significant role in these disorders. As many as 73.7\% of patients with MDS and BD had trisomy 8 [4], whereas trisomy 8 represented only 5\% of all MDS cases in another report [5]. BD (or BD-like syndrome) with trisomy-8-positive MDS often forms a distinct subset of patients. Gastrointestinal lesions are very common. Contrastingly, ocular involvement and HLA-B51 positivity are relatively rare [6]. Although an etiological link between BD, MDS, and trisomy 8 has not yet been revealed, the presence of trisomy 8 seems to result in an overexpression of several cytokine genes, which enhances neutrophil function [6].

A search of the relevant literature revealed some patients with BD or suspected BD who developed severe inflammation after receiving PPSV23 (Table 1). In 2012, Hügle et al., [7] first reported

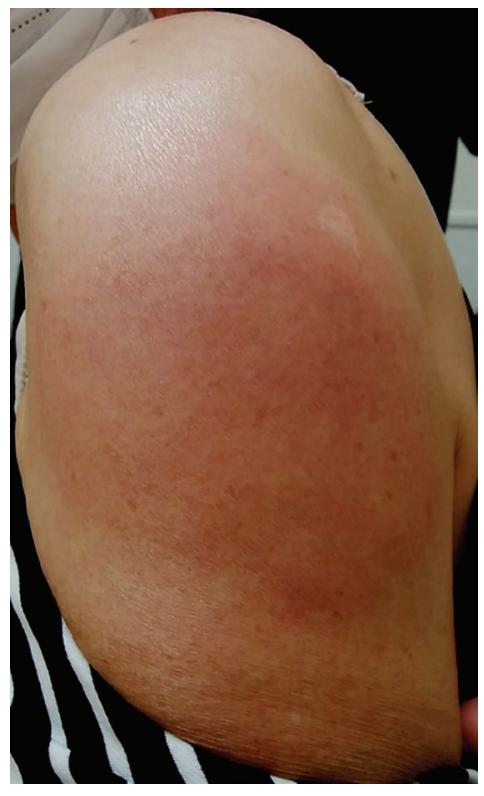

Figure 1. Pain, redness, and swelling at the injection site on the left upper arm. 


\begin{tabular}{|c|c|c|c|c|c|c|c|c|}
\hline $\begin{array}{l}\text { Case no. } \\
\text { [Ref.] }\end{array}$ & Age & Gender & Origin & Diagnosis & $\begin{array}{l}\text { Treatment } \\
\text { at time of } \\
\text { vaccination }\end{array}$ & $\begin{array}{l}\text { Local symptoms and } \\
\text { signs of infection site }\end{array}$ & $\begin{array}{l}\text { Associated symptoms } \\
\text { and signs }\end{array}$ & $\begin{array}{l}\text { CRP } \\
(\mathrm{mg} / \mathrm{L})\end{array}$ \\
\hline $1[7]$ & 32 & Male & Swiss & $B D$ & $\begin{array}{l}\text { Abatacept, } \\
\text { prednisolone } \\
(20 \mathrm{mg})\end{array}$ & $\begin{array}{l}\text { Ipsilateral axillar pain, } \\
\text { redness, calor, and } \\
\text { tenderness }\end{array}$ & $\begin{array}{l}\text { Fever, chills, nausea, } \\
\text { and vomiting }\end{array}$ & 385 \\
\hline $2[7]$ & 41 & Male & Turkish & BD & Etanercept & $\begin{array}{l}\text { Local pain, calor, } \\
\text { redness, and swelling }\end{array}$ & $\begin{array}{l}\text { Fever, shivering, } \\
\text { headache, and dyspnea }\end{array}$ & 223 \\
\hline $3[7]$ & 41 & Female & Turkish & $B D$ & Ibuprofen & $\begin{array}{l}\text { Local pain, calor, and } \\
\text { swelling }\end{array}$ & None & $\mathrm{N} / \mathrm{A}$ \\
\hline $4[7]$ & 46 & Male & Turkish & BD & Azathioprine & $\begin{array}{l}\text { Local pain, calor, and } \\
\text { swelling }\end{array}$ & Fever and asthenia & 158 \\
\hline $5[8]$ & 74 & Male & Japanese & Suspected BD & $\begin{array}{l}\text { Prednisolone } \\
(2.5 \mathrm{mg})\end{array}$ & $\begin{array}{l}\text { Local pain, calor, } \\
\text { redness, and swelling }\end{array}$ & $\begin{array}{l}\text { Fever, dyspnea, and } \\
\text { acute kidney injury }\end{array}$ & 132.5 \\
\hline 6 [9] & 64 & Male & Japanese & $\mathrm{BD}$ & $\begin{array}{l}\text { Prednisolone } \\
(3 \mathrm{mg})\end{array}$ & $\begin{array}{l}\text { Local pain, calor, } \\
\text { redness, swelling, and } \\
\text { tenderness }\end{array}$ & $\begin{array}{l}\text { Fever and acute kidney } \\
\text { injury }\end{array}$ & 386.4 \\
\hline $\begin{array}{l}\text { Present } \\
\text { case }\end{array}$ & 65 & Female & Japanese & $\begin{array}{l}\text { MDS with } \\
\text { trisomy } 8\end{array}$ & None & $\begin{array}{l}\text { Local pain, calor, } \\
\text { redness, and swelling }\end{array}$ & Fever and chills & 165.4 \\
\hline
\end{tabular}

four patients with BD who developed severe local and systemic inflammatory reactions to the first administration of PPSV23. No systemic adverse events were reported in their patients, who were inoculated with PPSV23 for autoimmune diseases other than BD. Although the precise pathophysiology was unclear, the authors proposed that the severe adverse reactions might have resulted from an aberrant activation of the inflammasome. To the best of our knowledge, this report is the first to describe a severe inflammatory reaction after PPSV23 vaccination in a patient with MDS and trisomy 8.

To conclude, we have described here a rare case of severe inflammatory response in a patient with MDS and trisomy 8 following the first administration of PPSV23. The present case may suggest a new BD-like presentation of trisomy-8-positive MDS. Additionally, the safety of PPSV23 for patients with trisomy-8-positive MDS should be further evaluated.

Keywords: Myelodysplastic syndrome, Trisomy 8, Behçet's disease, 23-Valent polysaccharide pneumococcal vaccine, Severe inflammatory syndrome, Severe inflammatory reaction

Anahtar Sözcükler: Miyelodisplastik sendrom, Trizomi 8, Behçet Hastalığı, 23-valan polisakkarit pnömokok aşısı, Şiddetli enflamatuvar yanıt sendromu, Şiddetli enflamatuvar reaksiyon

\section{Ethics}

Informed Consent: Informed consent was obtained from the patient.

\section{Authorship Contributions}

Data Collection or Processing: H.F., Y.M., K.E., M.S.; Literature Search: H.F., Y.M., K.E., M.S.; Writing: H.F.

Conflict of Interest: No conflict of interest was declared by the authors.

Financial Disclosure: The authors declared that this study received no financial support.

\section{References}

1. Moberley S, Holden J, Tatham DP, Andrews RM. Vaccines for preventing pneumococcal infection in adults. Cochrane Database Syst Rev 2013;2013:CD000422.

2. Oostvogels R, Petersen EJ, Chauffaille ML, Abrahams AC. Systemic vasculitis in myelodysplastic syndromes. Neth J Med 2012;70:63-68.

3. Marisavljević D, Kraguljac N, Rolović Z. Immunologic abnormalities in myelodysplastic syndromes: clinical features and characteristics of the lymphoid population. Med Oncol 2006;23:385-391.

4. Lin YC, Liang TH, Chang HN, Lin JS, Lin HY. Behçet disease associated with myelodysplastic syndrome. J Clin Rheumatol 2008;14:169-174.

5. Saumell $S$, Florensa $L$, Luño $E$, Sanzo $C$, Cañizo $C$, Hernández JM, Cervera J, Gallart MA, Carbonell F, Collado R, Arenillas L, Pedro C, Bargay J, Nomdedeu B, Xicoy B, Vallespí T, Raya JM, Belloch L, Sanz GF, Solé F. Prognostic value of trisomy 8 as a single anomaly and the influence of additional cytogenetic aberrations in primary myelodysplastic syndromes. $\mathrm{Br} J$ Haematol 2012;159:311-321.

6. Tada Y, Koarada S, Haruta Y, Mitamura M, Ohta A, Nagasawa K. The association of Behçet's disease with myelodysplastic syndrome in Japan: a review of the literature. Clin Exp Rheumatol 2006;24:S115-S119.

7. Hügle T, Bircher A, Walker UA. Streptococcal hypersensitivity reloaded: severe inflammatory syndrome in Behcet's disease following 23-valent 
polysaccharide Streptococcus pneumoniae vaccine. Rheumatology (Oxford) 2012;51:761-762.

8. Morita R, Ikegami Y, Furutama J, Watanabe M, Hashimoto K, Yamasaki M, Arita K. A suspected case of Behcet's disease with severe side effect to pneumococcal vaccination. Hiroshimaigaku 2014;67:695-698.
9. Kawasaki $Y$, Hayashi $K$, Ishikawa T, Onishi T, Tada $Y$, Watanabe S. A case of cellulitis-like reaction after pneumococcal vaccination. Hifubyoshinryo 2017;39:471-474

๑Copyright 2021 by Turkish Society of Hematology

Turkish Journal of Hematology, Published by Galenos Publishing House

\title{
Post-Chemotherapy Foamy Histiocytes in Bone Marrow Aspiration of a Child with Acute Lymphoblastic Leukemia
}

\author{
Akut Lenfoblastik Lösemili Bir Çocuğun Kemik Illiği Aspirasyonunda Kemoterapi Sonrası \\ Köpüklü Histiyositler
}

\author{
(D) Moeinadin Safavi1, (D) Zohreh Nozarian², (D) Farzad Kompani³ \\ ${ }^{1}$ Tehran, Iran \\ 2 Tehran University of Medical Sciences, Tehran, Iran \\ ${ }^{3}$ Tehran University of Medical Sciences, Division of Hematology and Oncology, Children's Medical Center, Pediatrics Center of Excellence, \\ Tehran, Iran
}

\section{To the Editor,}

Foamy histiocytes are usual in a variety of disorders such as metabolic and/or lysosomal storage disorders as well as prolonged total parenteral nutrition $[1,2]$. Post-chemotherapy foamy histiocytes have been reported only twice in bone marrow aspiration (BMA) smears according to our investigation, in one case of acute myeloid leukemia and one case of metastatic adenocarcinoma of the prostate $[3,4]$. Here we report a new case of post-chemotherapy foamy histiocytes in BMA smears.

An 8-year-old girl presented with bone pain mostly in the left pelvis and lower limbs, fever, and weight loss for 2 weeks. Paleness and lymphadenopathy in the left submandibular and supraclavicular regions were found on physical examination. No other abnormal findings or hepatosplenomegaly were seen according to the general physical examination, abdominal sonography, or chest $\mathrm{X}$-ray. Initial laboratory data showed a low hemoglobin level of $9.5 \mathrm{~g} / \mathrm{dL}$ (reference range: 11-16 $\mathrm{g} / \mathrm{dL}$ ) and platelet count of

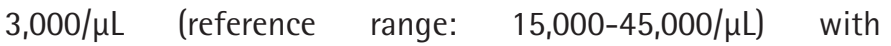
a leukocyte count of $5,500 / \mu \mathrm{L}$ (reference range: $4,000-10,000 / \mu \mathrm{L})$. Other prominent laboratory findings were elevated erythrocyte sedimentation rate of $110 \mathrm{~mm} / \mathrm{h}$ (reference range: $0-10 \mathrm{~mm} / \mathrm{h}$ ) and lactate dehydrogenase of 1,118 IU/L (reference range: $420-750 \mathrm{IU} / \mathrm{L}$ ).
BMA was performed and showed more than 90\% immature large cells with high nuclear to cytoplasm ratio and fine chromatin. In the flow cytometry of the BMA, these cells were positive for CD34, HLA-DR, TdT, CD10, CD19, and CD22 and were negative for CD3, CD20, CD117, and MP0. These findings confirmed the diagnosis of pre-B acute lymphoblastic leukemia NOS (pre-B ALL, NOS). Molecular analysis was negative for $\mathrm{t}(9 ; 22) / \mathrm{BCR}-\mathrm{ABL} 1, \mathrm{t}(12 ; 21) /$ ETV6-RUNX1， $\mathrm{t}(1 ; 19) / T C F 3-P B X 1$, and $\mathrm{t}(4 ; 11) /$ KMT2A-AFF1.

Standard chemotherapy was started according to the BerlinFrankfurt-Munster protocol including methylprednisolone at $60 \mathrm{mg} / \mathrm{m}^{2} /$ day, intravenous vincristine at $1.5 \mathrm{mg} / \mathrm{m}^{2} /$ day, intravenous daunomycin at $25 \mathrm{mg} / \mathrm{m}^{2} /$ day, intramuscular L-asparaginase at 6,000 units $/ \mathrm{m}^{2} /$ day thrice weekly for 9 doses, and an intrathecal injection of cytosine arabinoside (Ara C; $30 \mathrm{mg}$ ), methotrexate $(12.5 \mathrm{mg})$, and hydrocortisone (12.5 mg) [5].

BMA was performed 3 weeks later for evaluation of the early response to treatment after induction chemotherapy. Smears showed multiple foamy histiocytes (Figures $1 \mathrm{~A}$ and $1 \mathrm{~B}$ ) and initial remission according to BMA cytology and immunophenotyping. In these histiocytes, there were many variably sized large vacuoles, which differed from sea-blue macrophages. No 